\title{
Validation study of a scale of life quality evaluation in a group of pediatric patients infected by HIV
}

\author{
Estudo de validação de uma escala de qualidade de vida \\ em um grupo de pacientes pediátricos infectados pelo HIV
}

\author{
Dennis de Carvalho Ferreira ${ }^{1}$ \\ Mauro Romero Leal Passos ${ }^{1}$ \\ Norma de Paula Motta Rubini ${ }^{2}$ \\ Rosiangela Ramalho de Souza Knupp ${ }^{3}$ \\ José Alexandre da Rocha Curvelo ${ }^{4}$ \\ Helena Lucia Barroso dos Reis ${ }^{5}$ \\ Gesmar Volga Haddad Herdy ${ }^{5}$
}

\footnotetext{
${ }^{1}$ Setor de Doenças

Sexualmente

Transmissíveis,

Universidade Federal

Fluminense. Outeiro de São

João Batista s/nº, Campus do Valonguinho, Centro.

24210-150. Niterói RJ. carvalhoferr@yahoo.com.br

${ }^{2}$ Serviço de Aids Pediátrica, Departamento de

Imunologia e Alergia, Universidade Federal do Estado do Rio de Janeiro.

${ }^{3}$ Departamento de Odontologia Social e Preventiva, Faculdade de Odontologia, Universidade Federal do Rio de Janeiro.

${ }^{4}$ Departamento de Microbiologia Geral, Universidade Federal do Rio de Janeiro.

${ }^{5}$ Departament de Pediatria, Universidade Federal Fluminense.
}

\begin{abstract}
With the advent of potent antiretroviral therapy and the increase in life expectancy of pediatric patients infected with HIV, the quest for the promotion of enhanced quality of life should currently be the main focus in care of children with HIV/Aids. The scope of this study was to validate the Scale of Children's Quality of Life in a group of children infected with HIV receiving clinical care in Aids Service Units in Rio de Janeiro, Brazil. This scale consists of 26 questions and was tested on 100 children, with ages varying between 4 and 12, and their respective parents or guardians. Statistical analysis was conducted using canonical correlation and confidence interval anal$y$ sis and the $\chi^{2}$ test. The results showed that the cut-off point obtained was 49; the internal consistency with Cronbach's alpha was 0.73 for the children and 0.67 for parents or guardians. The response profile revealed marked satisfaction with aspects such as vacations and birthdays, though less satisfaction with items including hospitalization and playing alone. The conclusion was that the scale revealed satisfactory psychometric measurements, proving to be a reliable, consistent, valid and recommended instrument for measuring the quality of life of children infected with HIV.
\end{abstract}

Key words Quality of life, Children, HIV infection, Self-questionnaire, Validation
Resumo Atualmente, com o advento da terapia antirretroviral potente e o aumento da sobrevida dos pacientes pediátricos infectados pelo HIV, a busca da promoção de uma melhor qualidade de vida deve ser o foco principal na atenção a crianças vivendo com HIV/Aids. Torna-se necessária a utilização de um instrumento adequado a este grupo visando à investigação e à avaliação da sua qualidade de vida. Este estudo objetivou realizar validação da Escala de Qualidade de Vida da Criança em crianças infectadas pelo HIV atendidas em Serviços de Sida/Aids do Rio de Janeiro (RJ). Esta escala é composta de 26 perguntas e sua aplicação ocorreu em 100 crianças entre quatro e 12 anos e seus responsáveis. A análise estatística realizada utilizou correlações canônicas, intervalo de confiança e teste $\chi^{2}$. O ponto de corte obtido foi 49; a consistência interna expressa por um alfa de Cronbach da ordem de 0,73 para as crianças e 0,67 para os responsáveis. O perfil de resposta demonstrou satisfação elevada para itens como férias e aniversário, e os de menor satisfação foram internação $e$ brincar sozinho. Conclui-se que a escala apresentou medidas psicométricas satisfatórias, tornando-se um instrumento confiável, consistente, válido e recomendável de mensuração da qualidade de vida de crianças infectadas pelo HIV.

Palavras-chave Qualidade de vida, Crianças, Infecção pelo HIV, Autoquestionário, Validação 


\section{Introduction}

The acquired immunodeficiency syndrome (Aids) was first described in 1981 and as the years passed, this disease was disseminated to women and men with heterosexual behavior and to children by vertical transmission, taking the identity of a pandemic of rapid expansion, reaching potentially all the world population ${ }^{1}$.

With a growing number of cases in women in fertile age what is the responsible factor for the increase of the cases in children, since the main transmition via in these cases is the vertical one (virus transmition by the transplacental via, during delivery or through breast feeding ${ }^{2-5}$.

In Brazil, this transmition via is responsible for about $83,6 \%$ of the total of cases of Aids in children, according to data for the year $2004^{4}$. However, with the implantation of the chemoprophylaxis of the HIV vertical transmition ${ }^{6}$, it has occurred a high reduction in this transmition via, hoping it reaches rates smaller than 3\% as declare the scientific evidences ${ }^{4,7}$.

With the arrival of the combined antiretroviral therapy, we could observe an improvement in the clinical manifestations in children and it consequently resulted in an increase of their survival and in an improvement of their life quality . $^{8}$

On the other hand, the new therapy also imposed some challenges such as the regular time table of the medicines, what will involve the responses in the control and motivation of their use ${ }^{8,9}$; problems with bad therapy adhesion ${ }^{10}$; the medicines' palatability ${ }^{\prime}$; the adverse effects such as intolerance and toxicity $y^{8,9}$; the regular visits to the doctor and the regular exams ${ }^{9,1-13}$; the necessity of a hyper caloric diet ${ }^{14,15}$; an increase in the frequency of diseases such as caries (leading to a bigger inconvenient in food ingestion, leading also to problems of dental fitting, with possible phonation disturbances) ${ }^{16}$.

In the same way, the new therapy also imposed the conscience that these medicines still do not represent the definitive cure to the infection $^{8,10,12,13}$.

Allied to these factors there are those of psychosocial and emotional order, such as the responses loss'; the stigma of Aids orphans and victimization in education ${ }^{17}$; the rejection, the adoption or their insertion in foster homes; the moment of the diagnosis revelation ${ }^{17}$; the acceptance of their own infection and the familiarity with the disease ${ }^{17,18}$; the representations of themselves as infected ones ${ }^{18}$; the fear of the future ${ }^{18}$; their position at school ${ }^{19}$, with their friends ${ }^{18}$ and relatives $^{18}$; and the prejudice ${ }^{18}$.
Several there are the life dimensions of children who the HIV infection reaches, leading to a change in some concepts and ideas, such as the change of the stigma of "terminal disease" to "disease of chronic character", and the proposal of a new model of family and of evaluation of the infected individual ${ }^{8,17,20,21}$.

This way, we can conclude that this chronic disease affects the individual's life in emotional, physical and social factors. All these factors contribute to the patient's adjustment to his pathology and his perception of the impact in his life quality $^{22,23}$.

The attendance and accompanying of these children infected by HIV have only transcended the clinical, the laboratorial and the therapeutic aspects, considering a traditional model, having as its main focus these children's life quality ${ }^{1,8,21}$.

The infection by HIV/Aids brought a new boarding more qualitative in the attendance, with bigger emphasis in pediatric patients through a multi-disciplinary view imposed to the health professionals, with the finality of avoiding, disregarding or reducing the clinical manifestations, promoting their increase and their development inside the normality patterns and also preventing or diminishing the psychosocial consequences that they face ${ }^{8,19,20-23}$. Because, unfortunately, we haven't reached yet what could be considered a decisive factor in the disease elimination ${ }^{1,9}$.

To study the quality of life of pediatric patients infected by HIV is of extreme importance, since the child and the teenager have different degrees of perception of themselves and of the world, according to the period of development in which they are, and they can not be standardized in a single conception of personal satisfaction ${ }^{24}$. Another relevant point is what some studies have already shown, the perceptions of the parents and of the medical team that was in contact with the children under evaluation in general presented low rates of correlation with the childish self-evaluation ${ }^{25,26}$.

This way, by definition, quality of life with emphasis in health is understood as the individual's perception in relation to his situation inside the reality of his culture and of the values of the society in which he lives. This way, it points his goals, expectations, patterns and interests according to the description of the World Health Organization $(\mathrm{WHO})^{27}$.

Several scales have already been proposed by the literature to that finality in individuals without systemic alteration ${ }^{28-31}$ as well as in individuals who have pathologies of chronic character $^{29,32}$, such as the multiple sclerosis ${ }^{33}$, the epilep- 
$\mathrm{sy}^{23,34-39}$, the sarcoidosis ${ }^{39,40}$, the childhood neoplasies $^{22,41}$, the sleep apnea ${ }^{41}$ and rheumatic diseases inclusively in the adolescence ${ }^{42,43}$ and in children infected by HIV/Aids ${ }^{44-48}$.

In this specific group, there were used in general extensive, complex ${ }^{47}$ questionnaires of quality of life that preferentially tried to establish significance with the use of antiretroviral medicines, observing their influence in the child's life ${ }^{45-47}$. These questionnaires were restricted the clinical aspects of the infection $^{45,48}$, establishing correlations of low intensity with the psychosocial factors ${ }^{45}$.

Until today, no tool was capable to comprise all the domains of life of children without systemic alterations or of children in some kind of pathological state ${ }^{28,30,31}$, although all the formulated and validated ones were used to this finality, since the quality of life is a concept which incorporates the different faces of an individual's life and introduces one aspect of conception that is hard to quantify ${ }^{19}$.

In this context, the present study used the Child Quality of Life Scale (AUQUEI, Autoquestionnaire Qualité de Vie Enfant Imagé), developed by Manificat \& Dazord in 1997, translated and validated in Brazil by Assumpção Jr et al. in $2000^{27,49}$.

This questionnaire was chosen because it is a tool that proposes itself to evaluate the subjective state of present satisfaction, or better, the subjective sensation of well-being of the individual in focus, considering that the individuals under development (children) are capable of expressing themselves regarding their subjectivity. This questionnaire is, at the same time, considered useful and skilful to check the children's feelings regarding their present state, since it does not leave from inferences accomplished according to its performance and its productivity ${ }^{27,49}$.

Inside the big quantity of scales and questionnaires proposed to evaluate the quality of life by the literature, and, at the same time, because of the need of adequate instruments in our environment, this study's objective was to accomplish the validation of the Child Quality of Life Scale in a group of children infected by HIV that were under clinical attendance in services of Aids from Rio de Janeiro (RJ, Brazil).

\section{Methodology}

This is a descriptive, quantitative and observational study in which the quality of life scale application was accomplished in an individualized way by an interview in a group of children infected by HIV who were chosen randomly. During the questionnaire application, the children were not aware of their responses' answers, and the responses were not aware of the children's answers. The data were collected between March and July of the year 2005.

The sample was of 100 children infected by $\mathrm{HIV}$, who were under clinical attendance, in the pediatric HIV/Aids Ambulatories from the Centro Previdenciário de Niterói (CPN) and from the Hospital Gafrée e Guinle (HUGG), RJ, with age ranging from 4 to 12 years old. At the same time, these questionnaires were also applied to their responses (100 individuals), to acquire their perceptions of the children's quality of life, aiming its validation.

The children's responses were subdivided in mother, father, institutional caregiver (shelters and institutions' responses) and domicile caregiver (grandparents, uncles, cousins, adoptive parents).

The Aids services which acted as research field were chosen because they are centers of reference in the treatment of the infection by HIV for more than ten years, and because they were coordinated by qualified professionals.

The patients were attended in their days of monthly medical appointment, as part of the clinical routine, where after a raffle of the set children, the present study was explained to the responses and those who agreed to participate had to fill the identification form and signed the term of free and enlightened permission.

The scale was based on the point of view of the children's satisfaction viewed by four figures which are associated to several life domains, accessed by 26 questions which explored familiar and social relationships, activities, health, corporal functions and separation ${ }^{27,49}$.

Those domains were:

. Autonomy - Factor 1 (questions: 12, 15, 17, 18, 19 and 24) - regarding independence, relations with partners and evaluations;

. Leisure - Factor 2 (questions: 7, 9, 11, 21, 25 and 26) - regarding vacation, birthday, relation with grandparents;

. Functions - Factor 3 (questions: 1, 2, 4, 5, 8, 14 and 20) - regarding to school activities, meals, going to bed, going to see the doctor;

. Family - Factor 4 (questions: 3, 6, 10, 13, 16, 22 and 23) - regarding the opinion about the figures of their parents and about themselves.

The scale is a self-evaluation which uses the images and where the child answers the ques- 
tions and each one present a domain (in number of 4 ) and the answers (in number of 4) are represented with the help of faces which express different emotional states, like: very unhappy, unhappy, happy and very happy.

It is then asked to the child to point, without definite time, the answer that better corresponds to her feeling in front of the proposed domain (in this case, the presented question). However, it is initially asked to the child to present an experience lived during each alternative. This permits the child to comprehend the situations and to present her own experience. This way, the scale permits to obtain a satisfaction profile of the child in front of different situations. The used questionnaire was established as followed:

The answers obtained in the application of the scale of quality of life were punctuated from 0 to 3 according to faces' mood represented. The scale is a self-evaluation which uses the images and where the child answers the questions and each one present a domain (in number of 4 ) and the answers (in number of 4 ) are represented with the help of faces which express different emotional states, like: very unhappy, unhappy, happy and very happy.

It is then asked to the child to point, without definite time, the answer that better corresponds to her feeling in front of the proposed domain (in this case, the presented question). However, it is initially asked to the child to present an experience lived during each alternative. This permits the child to comprehend the situations and to present her own experience. This way, the scale permits to obtain a satisfaction profile of the child in front of different situations. The sum of this punctuation constitutes the score of each questionnaire.

The validation of an instrument of quality of life requires the evaluation of the obtained data by the application of this scale or questionnaire in individuals definite in time and place, to observation of the internal consistence and reliability of this instrument and its effectiveness ${ }^{29,33}$.

About the external validation, this scale was applied in a specific group of children infected by HIV, considering that the results obtained in the present study may be inferred to the target population.

Even though, the application of the same scale in the responses was done to verify the concordance of their answers with those from the children to contribute to the instrument reliability.

The test was not done a second time, since the concept of quality of life is mutable, depending on the situations of the moment of its appli- cation and a lot of patients were attended only once a month.

The results were statistically treated by the program SPSS version 10.0. With the finality of evaluating the existence of an association between two collections of variants in the groups of children and responses, it was done the analysis of canonical correlation. The comparison of each group's factors (children and responses) was done by the non parametric $\chi^{2}$ test.

To obtain the internal validation or reliability of the present study it was used the Cronbach's alpha coefficient.

This study was approved by the Ethics' Committee in Human Research from the Federal University of Fluminense (RJ).

\section{Results}

The questionnaire was applied in 106 patients and six children were excluded because they showed difficulty to comprehend the formulated questions.

The distribution of the children infected by HIV evaluated in this study, were separated according to gender and age, and showed that between the age of 4 to 6 , there was $23 \%$ among 10 girls and 13 boys. For the age between 6 to 8 the frequency was about $24 \%$ with 16 girls and 8 boys. For the group represented by the age between 8 to 10 showed $23 \%$ with 12 girls and 11 boys. Finally the last group was represented by the age between 10 to 12 with $30 \%$ among 19 girls and 11 boys. The female gender exhibited the highest frequency (57\%) followed by the age group in the class of 10 to 12 years old.

The distribution of the responses for the children infected by HIV who participated of this present study, was 14 institutional caregivers (14\%), 36 domicile caregivers (36\%), 44 mothers (44\%) and 6 fathers (6\%). This way we observe that half the children were under custody of the caregivers.

The mean of points obtained in each question was similar between children and responses as Graphics 1 and 2 show. The obtained answer profile demonstrates high satisfaction to the items concerning vacations (question 21), birthday (question 11), recreation (questions 1, 3 and 7), grandparents (question 25), photography (question 6) and television (question 26). In the same way, the items with smaller satisfaction are: internment (question 14), playing alone (question 15 ) and being distant of the family (question 23). 
The general score obtained was of 50,7 points, with standard deviation of 7,8 to the children and 50,1 points with standard deviation of 6,4 to the responses, without significant difference between the two groups $(\mathrm{p}=0,6922)$. There either was statistically significant difference $(\mathrm{p}=0,2519)$ between the feminine $(50 \pm 7,5)$ and the masculine $(51,8 \pm 7,5)$ populations and we can say that the samples of both genders presented equivalent scores. This way, to the confidence interval of $95 \%$, it was obtained a cut off point of 49 (2872 ) to the general population, under which, we may consider the quality of life of the studied population impaired.

The evaluated version showed to be satisfactory considering the internal effectiveness, with a
Cronbach's alpha coefficient of 0,73 for the children and of 0,67 for the responses. These results indicate that the characteristics are satisfactory regarding the reliability.

Considering the four factors which compose the scale (autonomy, leisure, functions and family), it was obtained positive correlation between all of them for the children and for the responses, characterizing the effectiveness of the scale construction (Tables 1 and 2).

The result indicates the factors 1 and 3, 1 and 4,2 and 3 and 2 and 4 as significant $(p<0,05)$ for the children, so it is clearly rejected the hypothesis of inexistence of association and, on the other hand, there is no relation between 1 and 2,2 and 4 and 3 and 4.

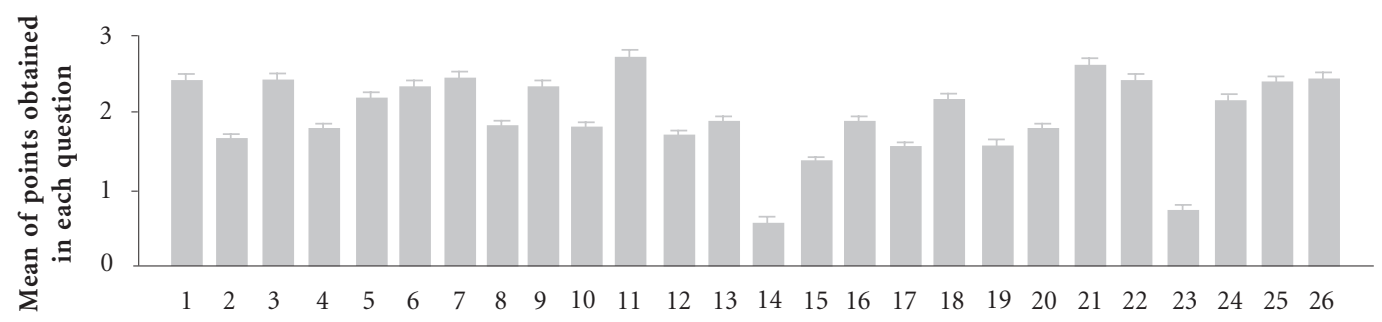

Number of questions

Graphic 1 . Mean of points obtained in each question of the questionnaire answered by children infected by HIV, from the Hospitals Gafrée e Guinle and CPN, RJ, 2005.

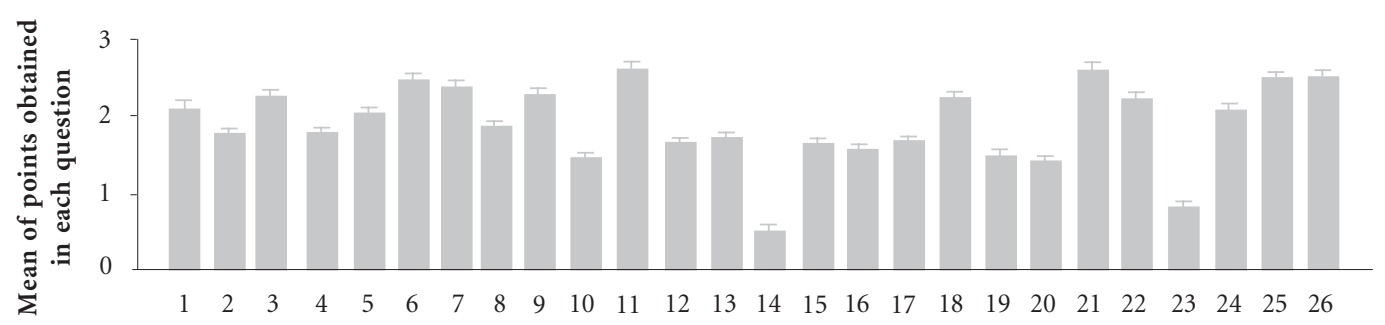

Number of questions

Graphic 2. Mean of points obtained in each question of the questionnaire answered by the responses of children infected by HIV, from the Hospitals HUGG and CPN, RJ, 2005. 
Table 1. Correlation among the four factors of the scale applied to children infected by HIV, from Hospitals Gafrée e Guinle and CPN, RJ, in 2005.

\begin{tabular}{|c|c|c|c|c|}
\hline Factors/Factors & Autonomy & Leisure & Functions & Family \\
\hline Autonomy & & 0,43856 & $0,58565^{*}$ & $0,58766^{*}$ \\
\hline Leisure & 0,43856 & & $0,64773^{*}$ & $0,64693^{*}$ \\
\hline Functions & $0,58565^{*}$ & $0,64773^{*}$ & & 0,45815 \\
\hline Family & $0,58766^{*}$ & $0,64693^{*}$ & 0,45815 & \\
\hline
\end{tabular}

${ }^{*} \mathrm{p}<0,05$

Table 2. Correlation among the four factors of the scale applied to responses by children infected by HIV, from Hospitals Gafrée e Guinle and CPN, RJ, in 2005.

\begin{tabular}{lcccc}
\hline \multicolumn{1}{c}{ Factors/Factors } & Autonomy & Leisure & Functions & Family \\
Autonomy & & 0,38383 & $0,58912^{*}$ & $0,57899^{*}$ \\
Leisure & 0,38383 & & $0,62889^{*}$ & $0,50494^{*}$ \\
Functions & $0,58912^{*}$ & $0,62889^{*}$ & & 0,48215 \\
Family & $0,57899^{*}$ & $0,50494^{*}$ & 0,48215 & \\
\hline
\end{tabular}

${ }^{*} \mathrm{p}<0,05$.

\section{Discussion}

The scale of life quality of the child was described as a multi-dimensional and generic instrument which permitted the mensuration of the life quality of a group of children infected by HIV, initially leaving from its validation in the study's population, and being characterized as objective ${ }^{27,49}$.

The present scale showed satisfactory psychometric properties, and it also counts on the help of images that come to the encounter of the playful universe of the child, stimulating her interest during the evaluation, since it presents easy application as described by its author ${ }^{27,49}$, what was confirmed in this study, including the four domains of life considered of great influence in the infantile development.

Another characteristic showed by the questionnaire was its facility to be reproduced, what identifies it inside the concepts of a scale considered ide$\mathrm{al}^{33}$, following the same model used when it was validated in $\mathrm{Brazil}^{28}$, as it was applicable in a group of children infected by HIV, classified as chronic patients, without going through alterations, signaling its flexibility, similar to when it was applied in children without systemic alterations ${ }^{27}$.

About its constitution, the questionnaire possesses a structural extension considered favor- able (26 questions) regarding other instruments that measure life quality, which vary from 10 to 151 items. This scale showed itself opportune to be used in pediatric patients, since this group is exposed to a higher degree of dispersion than grown ups. And, because it is not extensive, it was not tiring, so that it did not incur in information obliquity (induction of the children in their answers $)^{50}$.

The found results are useful in the evaluation of the influence of the care given to these patients and in measuring the disease's repercussion, and not in the incapacity generated by this ${ }^{33,45}$. Once these children are inserted in a program of multidisciplinary attendance in Aids (with the participation of doctors, nurses, psychologists, volunteers and others), what stimulates the necessity of the accomplishment of a stratified analysis of these punctuations to suggest to the services what factors need intervention ${ }^{29,33,39,45}$.

This way, studies ${ }^{45,46,47}$ evaluating life quality and doing correlations between the impact of some antiretroviral medicines and the adhesion to treatment are frequently described. Remaining focused in the biomedical tradition, emphasizing only clinical and therapeutical aspects, reducing other aspects of the patients' life as the social, cultural, psychological and emotional life 
experiences which directly influence the adhesion to the proposed treatment and to the fact of living with HIV ${ }^{19}$.

It becomes interesting to emphasize that the present researchers are not in ideal position to do a homogeneous and universal classification of quality of life to pediatric patients with pathologies of chronic character ${ }^{28,29,32,42}$.

The lack of suitable evaluation means to this specific group; the singularities of each disease $\mathrm{e}^{29,32,42}$, as the several levels of infection evolution and patients' adaptation ${ }^{51}$ are criterions that make difficult the quality of life evaluation.

In a general way, for children chronically sick, an extremely important point is the value of the negative experiences inside their life history, what allows us to check their tolerance to frustration (essential capacity of the human being), outlining their adaptation in front of conflicts and losses which compose their development in the evolutionary process ${ }^{52,53}$.

Added to this fact, children, in most of the times, present a vision of themselves and of the world that is very different from that of teenagers and grown ups (including their parents and the medical team $)^{25,26}$. As it was observed in a study which evaluated individuals with age under 15 years old and who possessed cancer diagnosis, inside the group of 124 components, 13 considered the disease a positive event in their lives $^{53}$. This justifies the importance of the application and validation of the present scale in children infected by HIV.

It is reasonable to say that, in 20 years, the infection by HIV incorporated concepts, prejudices and paradigms which characterize it, but that still are under transformation, as we can observe with the increase of the survival of the infected children, who are already able to cross the adolescence and reach the youth ${ }^{8,10,13,21}$.

Inside this reality, it is roused the interest in a healthy and safe sexual education in this age group, since scientific evidences show precocity in the first sexual relation in the age group between 11 and 13 years old, for men and women ${ }^{54}$. It is also observed greater vulnerability originating from faults or inconsistencies in preservatives' use, united to the high rate of sexual activity with different partners, constituting an increasing risky behavior for acquisition of sexually transmitted diseases (STD) and for dissemination of the infection by HIV, once his group is already infected by this virus ${ }^{54}$.

These observations become very revealing, because about $30 \%$ of our sample was between
10 and 12 years old. It is then pointed out the necessity of some specific educational programs to this group ${ }^{54}$.

About the responses' participation, we emphasize that half of them were caregivers, what shows that the separation of one parent or of both of them, reflecting the loss of them because of death or because of their incapacity to take care of their children, or even because of rejection. Some of these children are in infantile institutions; others are under guardianship of close relatives, or under care of adoptive parents, making clear the social risk to which they are exposed, even though it is sought mechanisms of psychosocial compensation.

These results are equivalent to those observed by another group of researchers ${ }^{45}$, who checked that less than $30 \%$ of the children infected by HIV lived with their parents and 50\% lived with responses constituted by relatives.

The similar answer pattern for the questions punctuation of the children and of their responses suggests the great nearness in terms of familiarity between these two groups, promoted by the pathological state of the infection by HIV, reinforcing their emotional and affective links. These data correspond to a requirement described as essential in an evaluation instrument of quality of life, which is to avail oneself of information from responses of the treatment with the child ${ }^{55}$.

This concordance of answers contributed to the reliability of this instrument, since it did not occur significant difference between the two groups $(p=0,6922)$. However, these findings differ from those which were already proposed in other studies, where it was considered that the concordance of responses' answers would be changed in cases of children with chronic diseases, because, in a distinct way, the grown up's evaluation is based in inferences about the real state of satisfaction of the child, anchored in their own level of cognition and affective development of grown up, different from the analysis of the reality accomplished by the child ${ }^{28}$.

The high satisfaction for the items concerned to vacation, birthday, amusement, grandparents, photography and television obtained in the answer profile show greater representation for the domains of leisure and family. These results agree with those observed by other authors regarding leisure, with a small variation for the domain of functions. This illustrates the leisure impact in childhood and, at the same time, the fact that the experience of a chronic disease is dynamic and complex, also reaching the patient's family ${ }^{34,36,39}$. 
The items relative to smaller satisfaction like internment, playing alone and being distant from family, repeating, in a similar way, the results of other authors that also used this scale ${ }^{28,49}$.

About the cut off point, it was 49 for the confidence interval of $95 \%$ (varying from 28 to 72 points), under which we may consider the life quality of the studied population impaired. This measure was also used in other studies, because the quality of life is an extremely subjective field and variable in its concepts, according to cultures, regions, pathological and psychosocial conditions, what differs it from the classic definitions of diseases and systemic alterations ${ }^{33,35}$.

To measure the internal consistence (internal effectiveness), the Cronbach's alpha coefficient was used. This test was applied to the children and to their responses and both of them were satisfactory, with values of 0.73 and 0.67 , respectively, similar to those observed by other authors in the validation of other scales of quality of life evaluation $^{33,35}$.

About the effectiveness of the construction of a scale, a collection of 26 variants tried to measure the satisfaction of children infected by HIV. These were divided in four domains regarding several dimensions of an individual's life, which were named factors. The existence of an association was evaluated (Tables 1 and 2), where occurred positive correlation between the four factors that compose the scale (autonomy, leisure, functions and family) for the children and for their responses. Some of these factors showed greater correlation intensity than others regarding the satisfaction profile of the child and of the grown up, since both of them possess different visions of life and of the world.

Regarding the importance of evaluating the quality of life of children infected by HIV, we may conclude that the used scale showed satisfactory psychometric measures, and it can be recommended as a consistent, reliable and valid instrument in this sample. Besides, it presents an easy application in this specific group of pediatric patients, when accomplished as an interview.

It can also be useful as a model for characterization of other groups of pediatric patients with other pathologies of chronic character, needing to be validated also in these groups ${ }^{56}$. In the same way, it was skillful to obtain the nature of the "health" and satisfaction states of the individuals from the present study regarding their life quality.

\section{Collaborations}

DC Ferreira assisted in all the stages of the article, especially in data gathering; MRL Passos and NPM Rubini helped to structure the study; RRS Knupp and GVH Gerdy conducted the statistical analysis and HLB Reis and JAR Curvelo organized the tabulation and results. 


\section{Referências}

1. UNAIDS. Report on the global HIV/AIDS epidemic: $4^{\text {th }}$ global report. Geneva: UNAIDS; 2004.

2. Kourtis AP. Prevention of perinatal HIV transmission: current status and future developments in antiretroviral therapy. Drugs 2002; 62(2)213-220.

3. Brasil. Ministério da Saúde. Definição nacional de caso de Aids em indivíduos menores de 13 anos, para fins de vigilância epidemiológica. Brasília: Ministério da Saúde; 2001.

4. Brasil. Ministério da Saúde. Programa Nacional de DST e Aids: recomendações para a profilaxia da transmissão vertical do HIV e terapia anti-retroviral em gestantes. Brasília: Ministério da Saúde; 2004

5. Succi RCM. HIV/Aids: reduzir a transmissão materno-infantil é necessário ou é possível? Jornal de Pediatria 1997; 73(2):65-66.

6. Lissauer T, Clayden G. Manual ilustrado de pediatria. Rio de Janeiro: Guanabara Koogan; 1998.

7. Brasil. Ministério da Saúde. Boletim Epidemiológico Aids e DST: dados epidemiológicos Aids. Brasília: Ministério da Saúde; 2004.

8. Rubini N. Aids pediátrica. In: Passos MRL, organizador. Deessetologia - DST 5. Rio de Janeiro: Cultura Médica; 2005. p. 167-178.

9. Leggot J. Oral manifestations of HIV infection in children. Oral Surg Oral Med Oral Pathol 1992; 73(2):187-193

10. Rubini N. Efeitos adversos dos ARVs em crianças e adolescentes. Ação Anti-Aids 2004; 51:8.

11. Brasil. Ministério da Saúde. Programa Nacional de DST e AIDS: guia de tratamento clínico da infecção pelo HIV em crianças. Brasília: Ministério da Saúde; 2004.

12. Directrices para el uso de antirretrovíricos en adolescents y adultos infectados por VIH1. Temas da actualidad: current topics. Rev Panam Salud Publica 2001; 10(3):202-216.

13. Bartlett JG. The Johns Hopkins Hospital: assistência clínica ao paciente com HIV/Aids - guia prático. Rio de Janeiro: Revinter; 1999

14. Gonçalves ES. Nutrição Superpositiva 2: para gestantes e crianças vivendo com HIV/Aids. Rio de Janeiro: Abia; 1999.

15. Thomaz PH. Manual de boa alimentação para pacientes portadores de HIV e Aids. São Paulo: BMS Virologia; 2000.

16. Ferreira DC, Dias APV, Godefroy P, Gardioli D. Aspectos orais da infecção pelo HIV em pacientes pediátricos: uma abordagem atual. DST - J Bras Doenças Sex Transm 2004; 16(2):53-57.

17. Carvalho CML, Braga VAB, Galvão MTG. Aids e saúde mental: revisão bibliográfica. DST - J Bras Doenças Sex Transm 2004;16(4):50-55.

18. Saldanha AAW, Figueiredo MAC, Coutinho MPL. Atendimento psicossocial à Aids: a busca pelas questões subjetivas. DST - J Bras Doenças Sex Transm 2004;16(3):84-91.

19. Schwarzstein J, Pinto TCR, Branco CAC. A Aids e a escola: nem indiferença, nem discriminação. Rio de Janeiro: Abia; 1993.
20. Terto Júnior V, Pimenta C, Parker R, Guimaraes M, Lima DB, Raxach JC. Qualidade de vida para pessoas vivendo com HIV/Aids: aspectos politicos, socioculturais e clínicos. Rio de Janeiro: Abia; 2004.

21. Reaman GH, Haase GM. Quality of life research in childhood cancer. Cancer 1996; 78(6):1330-1332.

22. Salgado PCB, Souza EAP. Impacto da epilepsia no trabalho: avaliação da qualidade de vida. Arq Neuropsiquiatr 2002; 60(2-B):442-445.

23. Hinds P. Quality of life in children and adolescents with cancer. Semin Oncol Nurs 1990; 6:285-291.

24. Eiser C. Children's quality of life measures. Arch Dis Child 1997; (77):347-350.

25. Cannig EH. Mental disorders in chronically ill children: case identification and parent-child discrepancy. Psychosom Med 1994; 56(2):104-108.

26. Word Health Organization (WHO). Study Protocol for the World Health Organization Project to develop a quality of life assessment instrument (WHQOL). Quality of Life Res 1993; 2:153-159.

27. Assumpção Jr RFB, Kuczynski E, Sprovieri MH, Aranha EMG. Escala de avaliação de qualidade de vida. Arq Neuropsiquiatr 2000; 58(1):119-127.

28. Patrick DL, Deyo RA. Generic and disease-specific measures in assessing health status and quality of life. Medical Care 1989; 27(3):S217-S232.

29. Hepner KA, Sechrest L. Confirmatory factor analysis of the Child Health Questionnaire-Parent Form 50 in a predominantly minority sample. Quality of Life Research 2002; 11(8):763-773.

30. Garrat AM, Ruta DA, Abdalla MI, Buckingham JK, Russell IT. The SF 36 health survey questionnaire: an outcome measure suitable for routine use within the NHS? BMJ 1993; 306(29):1440-1444.

31. Younossi ZM, Guyatt G, Kiwi M, Boparai N, King D. Development of disease specific questionnaire to measure health related quality of life in patients with chronic liver disease. Gut 1999; 45:295-300.

32. Mendes MF, Balsimelli S, Stangehaus G, Tilbery CP. Validação de escala de determinação funcional da qualidade de vida na esclerose múltipla para a língua portuguesa. Arq Neuropsiquiatr 2004; 62(1): 108-113.

33. Fernandes PT, Souza EAP. Inventário simplificado de qualidade de vida na epilepsia infantil: primeiros resultados. Arq Neuropsiquiatr 1999; 57(1):40-43.

34. Souza EAP. Questionário de qualidade de vida na epilepsia: resultados preliminares. Arq Neuropsiquiatr 2001; 59(3-A):541-544.

35. Guimarães CA, Souza EAP, Montenegro MA, Cendes F, Guerreiro MM. Cirurgia para epilepsia na infância: avaliação neuropsicológica e de qualidade de vida. Arq Neuropsiquiatr 2003; 61(3-B):786-792.

36. Frayman L, Cukiert A, Forster C, Ferreira VB, Buratini JA. Qualidade de vida de pacientes submetidos à cirurgia de epilepsia. Arq Neuropsiquiatr 1999; 57(1):30-33

37. Salgado PCB, Souza EAP. Qualidade de vida em epilepsia e percepção de controle de crises. Arq Neuropsiquiatr 2001; 59(3-A):537-540. 
38. Souza EAP. Qualidade de vida na epilepsia infantil. Arq Neuropsiquiatr 1999; 57(1):34-39.

39. Cox CE, Donohue JF, Brown CD, Kataria YP, Judson MA. The Sarcoidosis Health Questionnaire. Am J Respir Crit Care Med 2003; 168:323-329.

40. Bigal ME, Fernandes LC, Moraes FA, Bordini CA, Speciali JG. Prevalência e impacto da migrânea em funcionários do Hospital das Clínicas da Faculdade de Medicina de Ribeirão Preto - USP. Arq Neuropsiquiatr 2000; 58(2-B):431-436.

41. Bradlyn AS, RitcheyAK, Harris CV. Quality of life research in pediatric oncology. Cancer 1996; 78(6):1333-1339.

42. Machado MA, Prado LB, Carvalho LB. Francisco S, Silva AB, Atallah NA, Prado GF. Quality of life of patients with obstructive sleep apnea syndrome treated with an intraoral mandibular repositioner. Arq Neuropsiquiatr 2004; 62(2-A):222-225.

43. Ruperto N, Ravelli A, Pistorio A. Malattia C, Cavuto S, Gado-West L, Tortorelli A, Landgraf JM, Singh G, Martini A. Cross-cultural adaptation and psychometric evaluation of the Childhood Health Assesment Questionnaire (CHAQ) and the Child Heath Questionaire (CHQ) in 32 countries: review of the general methodology. Clin Exp Rheumatol 2001; 19(Supl.23):S1-S9.

44. Varni JW, Seid M, Smith KT, Burwinkle T, Brown J, Szer IS. The PedsQL in pediatric rheumatology: reliability, validity, and responsiveness of the Pediatric Quality of Life Inventory Generic Core Scales and Rheumatology Module. Arthritis \& Rheumatism 2002; 46(3):714-725.

45. Préau M, Leport C, Salmon-Ceron D. Health-related quality of life and patient-provider relationships in HIV-infected patients during the first three years after starting PI-containing antiretroviral treatment. Aids Care 2004; 16(5):649-661.

46. Nicolas J, Dazord A, Manificat S. Evaluation of life quality for children infected by HIV: validation of a method and preliminary results. Pediatr Aids HIV Infect 1996; 7(4):254-260.

47. Eriksson LE, Bratt GA, Sandstrom E, Nordström G. The two-year impact of first generation protease inhibitor based antiretroviral therapy (PI-ART) on health-related quality of life. Health and Quality of Life Outcomes 2005; 3(32):1-8.
48. Storm DS, Boland MG, Gortmaker SL, He Y, Skurnick J, Howland L, Oleske JM. Pediatric Aids Clinical Trials Group Protocol 219 Study Team: protease inhibitor combination therapy, severity of illness, and quality of life among children with perinatally acquired HIV-1 infection. Pediatrics 2005; 115(2):173-182.

49. Pearson DA, McGrath NM, Nozyce M, Nichols SL, Raskino C, Brouwers P, Lifschitz MC, Baker CJ, Englund JA. Predicting HIV disease progression in children using measures of neuropsychological and neurological functioning. Pediatrics 2000; 106(6):110.

50. Manificat S, Dazord A. Évaluation de la qualité de vie de l'enfant: validation d'un questionnaire, premiers résultats. Neuropsychiatr Enfance Adolesc 1997; 45(3):106-114.

51. Medronho RA, Carvalho DMC, Bloch KV, Luiz RR, Werneck G. Epidemiologia. São Paulo: Atheneu; 2003.

52. Postlethwaite RJ, Garralda ME, Eminson DM. Reynolds J. Lessons from psychosocial studies of chronic renal failure. Arch Dis Child 1996; 75(5):455-459.

53. Jenney ME, Campbell S. Measuring quality of life. Arch Dis Child 1997; 77:347-350.

54. Holmes HA, Holmes FF. After ten years, what are the handicaps and life styles of children treated for cancer? Clin Pediatr 1975; 14:819-823.

55. Dias APS, Santos DDG, Ferreira DC, Passos MRL, Arze WNC. Estudo comparativo: perfil dos adolescentes atendidos numa clínica de DST nos anos de 1995 e 2003. Adolescência \& Saúde 2005; 2(2):15-24.

56. Mulhern RK, Horowitz ME, Ochs J, Friedman AG, Armstrong FD, Copeland D, Kun LE. Assessment of quality of life among pediatric patients with cancer: psychological assessment. J Consult Clin Psychol 1989; 1(2):130-138.

Artigo apresentado em 30/09/2008

Aprovado em 24/06/2009

Versão final apresentada em 04/09/2009 